\title{
Jednodniówka TAK - lektura w perspektywie intermedialnej
}

Krystyna Pietrych

TEKSTY DRUGIE 2021, NR 1, S. 341-359

DOI: 10.18318/td.2021.1.21 | ORCID: 0000-0001-9796-185X

\section{Drzed niemal czterdziestu laty Andrzej K. Waśkiewicz pisał:}

Jeśli wierzyć wspomnieniom, pierwszą programową publikacją polskich futurystów była ulotka Tak. [...]. Należy [...] przypuszczać, że ulotka ukazała się w ostatnim kwartale 1918 roku. Anatol Stern, który przypomina w Futurystach polskich $i$ innych atmosferę pierwszych wystąpień, mówi o „wydanej [...] w r. 1919 małej kolorowej ulotce pt. «Tak». Ulotka nie zachowała się w zbiorach polskich, poza przytoczonym wyżej fragmentem [traktującym o tym, co zapamiętał Wat, a o czym mowa będzie dalej - K.P.] nie znana jest jej treść. A znajomość tej publikacji, pewna informacja o czasie jej wydania mogłyby rozjaśnić wiele spraw. ${ }^{1}$
Krystyna Pietrych

- dr hab. prof. UŁ, kierownik Zakładu Literatury i Tradycji Romantyzmu UŁ, kierownik Interdyscyplinarnego Centrum Badań Humanistycznych UŁ. Redaktor naczelna rocznika „Czytanie Literatury. Łódzkie Studia Literaturoznawcze". Ostatnio opublikowała O czym (nie) mówiq poeci? (2019). Kontakt: pietrych@op.pl 
Najważniejsze z tych spraw są dla badacza kwestie dotyczące chronologii i kolejności wystąpień futurystów warszawskich i krakowskich:

W sporze o pierwszeństwo racje są więc po stronie ekipy krakowskiej, tym bardziej że nie odnaleziono prasowych publikacji Sterna sprzed jego publikacji książkowych. [...] [Jednak - K.P.] przyjęcie, iż ukazała się ona [jednodniówka Tak] w r. 1918, pozwoliłoby pierwszeństwo przyznać futurystom warszawskim. ${ }^{2}$

Dziś to pierwszeństwo możemy już przyznać Anatolowi Sternowi i Aleksandrowi Watowi, wskazując jako pierwszy druk programowy polskich futurystów ulotkę Tak, która ukazała się, jak podaje Waśkiewicz, w ostatnim kwartale 1918 albo na początku roku następnego 3 . Odnaleziona w archiwum Egidio Marzony w Dreźnie, opublikowana w 2019 roku w numerze 3 „Tekstów Drugich", tamże zaprezentowana i poddana szczegółowej interpretacji przez Beatę Śniecikowskąa , pierwsza zbiorowa publikacja rodzimego futuryzmu jest istotna nie tylko ze względów periodyzacyjnych, lecz także - a właściwie przede wszystkim - z powodu wielości znaczeń, jakie ze sobą niesie, i kontekstów, które aktywizuje i otwiera. Dziś, po upływie z górą stu lat od jej wydania, warto jednodniówkę Tak usytuować zarówno w perspektywie literaturoznawczej, jak i w przestrzeni międzyartystycznej, wyznaczonej badaniami mieszczącymi się w obszarze tzw. nowej komparatystyki, a ściślej - komparatystyki intermedialnej ${ }^{5}$. Moja propozycja zatem, w przeciwieństwie do czytania pierwszego (kanonicznego?) zaproponowanego przez Śniecikowską, odchodzi od ujęcia literaturocentrycznego na rzecz oglądu biorącego pod uwagę kształt werbalno-obrazowy ulotki, łączącej różne dyskursy i tradycyjnie odrębne dziedziny sztuki. Ten inny sposób lektury uwzględnia jako

2 Tamże, s. 38.

3 Kwestia datowania nie jest jednoznaczna. Krzysztof Jaworski pisze, że ulotka ukazała się z końcem grudnia 1918 roku lub na początku stycznia 1919 roku; por. K. Jaworski Kronika polskiego futuryzmu, Uniwersytet Jana Kochanowskiego w Kielcach Instytut Filologii Polskiej, Kielce 2015, s. 65.

4 Zob. B. Śniecikowska TAK odnalezione! Pierwsze czytanie pierwszej ulotki polskich futurystów, „Teksty Drugie” 2019 nr 3. Beacie Śniecikowskiej bardzo dziękuję za przekazanie kolorowego skanu ulotki Tak, bez którego niemożliwa byłaby moja propozycja jej odczytania. Dziękuję również przyjaciołom z Zakładu Literatury i Tradycji Romantyzmu UŁ za interesującą dyskusję nad moim tekstem.

5 Zob. A. Hejmej Komparatystyka. Studia literackie - studia kulturowe, Universitas, Kraków 2013, zwłaszcza s. 97-121. 
niezmiernie istotny element notację graficzną rozpatrywanej publikacji oraz poddaje ją interpretacji w optyce intermedialnej. Iluzją jest bowiem zwłaszcza dziś „koncepcja czystego środka wyrazu”. Jak zauważa Andrzej Hejmej, „intermedialność określa charakter dzisiejszej komunikacji kulturowej, bycie w społeczeństwie medialnym, sposób myślenia o współczesności" ${ }^{\prime}$, co z jednej strony wyznacza specyfikę naszego horyzontu odbiorczego, z drugiej zaś intermedialność

odnosi się - pisze badacz - do nowej estetyki, nazywanej czasami wprost estetyką intermedialności, zrywającej jednocześnie z różnymi tradycjami i „,czystych" estetyk, i estetyk „eklektycznych"; [...] oznacza [także - K.P.] wszelkie możliwe związki i fuzje sztuk $[\ldots]^{8}$

Intermedialność jest zarówno cechą dystynktywną ulotki Tak, jak i winna być, jak sądzę, preferowanym trybem jej odbioru. Oglądana z dzisiejszej perspektywy specyfika awangardowych publikacji z początku XX wieku, scalająca różne dyskursy i tradycyjnie uznawane za odrębne dziedziny sztuki, ujawnia zaskakująco dużo podobieństw z przedmiotem współczesnej refleksji dotyczącej funkcjonowania literatury jako medium łączącego elementy językowe, wizualne i dźwiękowe, które należałoby badać nie tylko literaturoznawczymi narzędziami. Taki sposób widzenia zaproponowała już u progu wieku XXI Maryla Hopfinger, pisząc o literaturze intermedialnej i obejmując tym terminem m.in. prekursorskie utwory Mallarmégo, kaligramy Apollinaire'a, wiersze wizualne Czyżewskiego czy Europę Sterna w opracowaniu plastycznym Mieczysława Szczuki. Badaczka zauważa, że „wieloznaczność tekstu współustanawia i unaocznia przestrzenny wymiar tekstu”`. Komentując zaś jeden z kaligramów, konstatuje:

[s]ymultaniczna konstrukcja Listu oceanicznego wyzwala - autora i odbiorcę - od linearności normalnie drukowanego tekstu, od

6 D. Higgins Intermedia, przeł. M. i T. Zielińscy, w: tegoż Nowoczesność od czasu postmodernizmu oraz inne eseje, wybór, oprac. i posłowie P. Rypson, słowo/obraz terytoria, Gdańsk 2000, s. 118; cyt. za: A. Hejmej Komparatystyka, s. 99.

7 A. Hejmej Komparatystyka, s. 99.

8 Tamże.

9 M. Hopfinger Doświadczenie audiowizualne. O mediach w kulturze współczesnej, Sic!, Warszawa 2002, s. 163. 
jednokierunkowości uporządkowania w czasie, od "przedtem" i „potem” w strukturze utworu. Jednoczesności jego elementów odpowiada graficzny układ całości, który odnosi się także do współwystępowania różnych technik komunikacyjnych w kulturze XX wieku. Kaligramatyczna twórczość Apollinaire'a działała na rzecz zbliżenia pomiędzy komunikacyjnym statusem pisma i obrazu, wydobywała obrazową funkcję słowa i znaczeniową rolę obrazu. ${ }^{10}$

Jednodniówka Tak, podobnie jak kaligramy, konstytuuje nierozerwalny związek między elementami werbalnymi i ikonicznymi, czyniąc je równorzędnymi współkomponentami semantyki tekstu. Warto zatem do jej odczytania sięgnąć po propozycje zaczerpnięte z innych niż stricte literaturocentryczny dyskursów.Tę potrzebę ostatnimi czasy uświadomił, poza działaniami lokującymi się w przestrzeni komparatystyki intermedialnej, również zwrot ikoniczny, którego jednym z najważniejszych postulatów było odejście od czytania obrazów jako odpowiednika lektury tekstu. Jak trafnie zauważyła Anna Kałuża:

Konsekwencją zwrotu obrazowego i podjęcia badań nad artystycznością w transmedialnej perspektywie byłyby, najogólniej mówiąc, dwa efekty: unieważnienie prymatu językowego modelu dla wszystkich innych reprezentacji, ekspresji i praktyk artystycznych oraz próba pomyślenia niebinarnego układu kulturowego, w ramach którego uznaje się, że wszystkie media są mediami mieszanymi. ${ }^{11}$

W dobie kultury wizualnej, którą awangardowe eksperymenty niewątpliwie antycypowały, warto spojrzeć na nasze rodzime „izmy” początku poprzedniego stulecia inaczej niż dotychczas, tzn. odchodząc od postaw stojących na straży odrębności poszczególnych sztuk na rzecz oglądu całościowego, w którym żadna dziedzina nie jest ani uprzywilejowana, ani całkowicie osobna, a żaden dyskurs nadrzędny lub podrzędny wobec innego. W tej właśnie perspektywie interpretować będę pierwsze wystąpienie Sterna i Wata. Nie będzie więc interesować mnie tu w głównej mierze perspektywa historycznoliteracka, choć kontekstowo rozważania tego typu także się pojawią. Przede wszystkim jednak chcę usytuować ulotkę Tak, ze względu na jej charakter

Tamże, s. 165 . 
werbalno-obrazowy, w przestrzeni inter-, a nawet transmedialnej. Warto raz jeszcze przytoczyć słowa śląskiej badaczki:

na realizacje ujmowane dotąd w ramach dwóch różnych systemów, uznawanych za konkurencyjne lub przekładalne na siebie, można spojrzeć z perspektywy transmedialnej. [...] Najważniejsze w tym kontekście wydaje się przekonanie, że wszystkie [literackie - K.P.] realizacje są obrazowo-wizualne, nie tylko te, które mają komponent niewerbalny czy niepiśmienny. ${ }^{12}$

Jeśli ulokujemy młodzieńcze dokonanie Sterna i Wata w horyzoncie zakreślonym przez nową komparatystykę i zwrot pikturalny, ujawni się heterogeniczność tego medium, rozpatrywanego dotąd przede wszystkim jako tekst literacki.

Jak pisze Tomasz Załuski:

W odróżnieniu od intermedialności, akcentującej element syntezy praktyk związanych z różnymi mediami, transmedialność odsyła do dynamiki przejścia danej praktyki z jednej dziedziny medialnej w inną, a także akcentuje wewnętrzną heterogeniczność powstającego w tym procesie wytworu. ${ }^{13}$

Oczywiście oba terminy stosowane są dziś przede wszystkim w odniesieniu do współczesnej kultury medialnej. Sądzę jednak, że ich użycie w kontekście dokonań awangardowych jest w pełni uzasadnione i może przynieść ciekawe efekty - z dokonującej się zmiany paradygmatu kultury zdawał sobie sprawę Tadeusz Peiper już w roku 1922, pisząc: „Świat się zmniejsza, a zwiększa się widnokrąg i słuchokrąg człowieka. Zmienia się to, co można nazwać czuciem świata"14. Dziś, po blisko stu latach od

12 Tamże, s. 40.

13 T. Załuski Transmedialność?, w: Sztuki w przestrzeni transmedialnej, red. T. Załuski, ASP, Łódź 2010, s. 11.

14 T. Peiper Radiofon, w: tegoż Pisma, t. 1: Tędy, Nowe usta, Wydawnictwo Literackie, Kraków 1972, s. 240; cyt. za: A. Hejmej Komparatystyka intermedialna, w: Między dyskursami, sztukami, mediami. Komparatystyka jutra, red. E. Szczęsna, P. Kubiński, M. Leszczyński, Universitas, Kraków 2017, s. 203. 
powyższej diagnozy papieża awangardy mówi się o „współczesnej rekonfiguracji aisthesis" ${ }^{15} \mathrm{~W}$ związku z zasadniczą przemianą wzorca werbalnego na audiowizualny i jego wpływem na postrzeganie i rozumienie świata, co uruchamia aintelektualną percepcję rzeczywistości ${ }^{16}$. Początki tego procesu przypadają na pierwsze dekady minionego stulecia. Warto zatem - podążając tropem łódzkiego kulturoznawcy - zadać wynikające z przyjęcia takiej perspektywy pytania i wykorzystać je do określenia specyfiki eksperymentów z początku XX wieku:

Co się [...] dzieje, zanim „krzyżujące” się sztuki ulegną syntezie i dadzą początek nowemu (inter)medium? Co się dzieje, gdy do takiej syntezy w ogóle nie dochodzi, gdy ze „skrzyżowania” sztuk powstaje heterogeniczna hybryda, utrzymująca się w orbicie oddziaływania nazwy danej praktyki artystycznej, rozszerzająca, redefiniująca lub rozrywająca jej ramy, bądź też zdająca wymykać się jednoznacznemu nazwaniu? Jak odnieść się do sytuacji, w której wartością staje się nie synteza i unifikacja, lecz sama „tranzytowość", „przechodniość"?17

Pytania te, dotyczące statusu owego „nowego (inter)medium”, wyznaczają pole, w którym sytuuję pierwsze programowe wystąpienie polskich futurystów, tak by wydobyć jego wizualno-werbalną jedność niedającą się zredukować, jak czyni jego pierwsza czytelniczka, do dyskursu językowego i medium pisma.

\section{**\%}

Jednodniówka Tak wiodła do niedawna, jako się rzekło, żywot na pół legendarny. Wat we Wspomnieniach o futuryzmie z początku 1930 roku, a więc ponad dekadę od jej publikacji, pisał:

Pierwszym występem była mała ulotka na błękitnym papierze zatytułowana Tak. Przypominam sobie tylko jedno zdanie: „owrzodziałe słupiska tomaszowej niewiary". Z tego frazesu i tytułu można sobie o niej urobić

\footnotetext{
15 A. Hejmej Komparatystyka intermedialna, s. 203.

16 Tamże.

17 T. Załuski, Transmedialność?, s. 11.
} 
pojęcie: była naszpikowana symbolami i głosiła bezwzględną aprobatę dzisiejszości. ${ }^{18}$

Porównanie tego, co Wat zapamiętał, z tym, co widnieje na niewielkiej kartce, nie tylko ujawnia mistyfikujące działanie pamięci, przekształcające "tomaszowe słupiska zgrzybiałego chramu / owrzodzone kolumny" w „owrzodziałe słupiska tomaszowej niewiary", ale również - co istotne - pozwala określić pierwotną kolorystykę tła oraz wskazać jednoznacznie autorską intencję; oczywiście jeśli pod tym względem zawierzyć pamięci Wata. Wydaje się jednak, że łatwiej zapamiętać dominującą barwę i zamierzony cel publikacji niż konkretne sformułowanie w jego oryginalnym kształcie.

Tak opisuje pierwszą publikację polskiego futuryzmu ${ }^{19}$ jej pierwsza badaczka:

Cieniutka kartka zeszytowego formatu, w niczym nieprzypominająca wielkoformatowych płacht późniejszych manifestów polskiego futuryzmu, niegdyś najpewniej błękitna, dziś pożółkła, lekko zielonkawa. Bibułkowy papier doskonale przechował jednak awangardowe - choć kojarzone głównie z konstruktywizmem - kontrasty czerwieni i czerni liter oraz, naturalnie, same kontrasty rozmiaru czcionek. Rozchwiany słup druku musiał u progu międzywojnia dezorientować dość przypadkowych odbiorców: rzecz napisana przez nastoletnich jeszcze Aleksandra Wata i Anatola Sterna ukazała się najpewniej pod koniec 1918 lub na samym początku roku $1919^{20}$.

18 A. Wat Wspomnienia o futuryzmie, w: tegoż Publicystyka, zebrał, oprac., przypisami i wstępem opatrzył P. Pietrych, Czytelnik, Warszawa 2002, s. 138; por. ciekawą analizę zapamiętanego przez Wata fragmentu - P. Graf Automobil w pędzie. Studia o futuryzmie i futurystach, Wydawnictwo Naukowe UAM, Poznań 2018, s. 19-21.

Mianem futurystycznej zwykło się określać młodzieńczą twórczość Wata. Można mieć wątpliwość co do trafności tej nazwy (miał je również sam Wat), większe powinowactwa łączą bowiem, moim zadaniem, awangardowe dokonania autora Mopsożelaznego piecyka z dadaizmem. Pisałam o tym szerzej w tekście Dadaistyczne z ducha poszukiwania młodego Wata, w: Impuls dadaistyczny w polskiej sztuce i literaturze dwudziestowiecznej, red. P. Kurc-Maj, P. Polit, Muzeum Sztuki w Łodzi, Łódź 2017. 


\title{
T A K
}

\author{
Jaskrawiącym się wrzaskiem \\ rżorykiem NEOFUTURÓW \\ przygważdżamy do rozkrzyża sromu \\ robactwo ludzkie łzawo wyśpiewne w rzygownym \\ błotku Mglistego
}
Kruszymy zębami brzeżki kruża lawiąc wargi swe
i sklepienie swego nieba alkoholem eteru
Krzyczymy cialem swoim
w jaskrzach
w dżwięczach lir
w zastyglym stężałym chcę

\section{SIEBIE}

w glorzystym Pramuskule

slońcowe ziemie z mordami spienionemi

od śmigu nam nieznane

wkolysane w rytmy fal fal rytmu nie znaja

zmorne szaleństwo rozżarzonych kraterów miast

Jesteśmy

tomaszowe slupiska zgrzybiałego chramu

owrzodzone kolumny

rozkonwulsjowane upojnie w podrygach

Czekamy na Niego

PRZYJDŹ 
Zacznijmy od kształtu materialnego raz jeszcze, gdyż to, co widzimy, wydaje się istotniejsze od tego, co możemy (nie bez trudu) przeczytać. Zwłaszcza w pierwszym momencie, gdy rzucając na ulotkę okiem, postrzegamy zrazu kilka jej najbardziej wyrazistych cech wizualnych. Po pierwsze, gdy była jeszcze błękitna, barwę nieoczywistego i niecodziennego tła. Po drugie, rozkołysaną, rozedrganą, jakby niestabilną kolumnę tekstu, zapisanego w dziwnie niesystemowy, „niespokojny”, a więc rozbijający statyczność pisma sposób, eksponujący zaś jego dynamikę. Ten graficzny brak ładu i spójności realizowany jest zarówno w przestrzeniach międzywersowych (różne, „skokowe" odległości między nimi), jak i w odstępach pomiędzy słowami w poszczególnych wersach, co może w jakiejś mierze przypominać schodkowe wiersze Majakowskiego. Po trzecie, czcionki kontrastują rozmiarem, krojem, pogrubieniami, pojawiającymi się małymi i wielkimi literami i oczywiście zastosowanymi kolorami: czarnym i czerwonym. Na pierwszy rzut oka typografia może sprawiać wrażenie zbyt pośpiesznie złożonej, byle jakiej, niepokojąco niezbornej. Właśnie owa „niezgrabność” wizualna działa na odbiorcę w pierwszym kontakcie najsilniej, prowokując do podjęcia prób okiełzania chaotycznego obrazu i poszukiwania jakiejś reguły organizującej całość obrazu. Jest kilka elementów, które mogą się stać stabilizującymi punktami oparcia. Taką funkcję pełni quasi-symetryczna konstrukcja tekstu opierająca się na zapisanych wersalikami: inicjalnym TAK i końcowym PRZYJDŹ oraz środkowym, zapisanym kolorem czerwonym dystychu: „SIEBIE / w glorzystym Parmuskule". Przy czym elementami wprowadzającymi porządek wizualny są tu nie tylko wielkie litery, lecz także podział wyraźnie segmentujący tekst na dwie wzajem symetryczne części, z krótkim, dwuwersowym fragmentem pośrodku, pełniącym funkcję wizualnego centrum komunikatu. Jednak elementy porządkujące osłabione zostają przez kapryśne pojawianie się w drukowanej rozfalowanej kolumnie słów zapisanych kolorem czerwonym w przypadkowych miejscach, sprawiających wrażenie jakby wybrano je nie celowo, ale na chybił trafil.

Czy te pierwsze wrażenia wzrokowe mają jakieś znaczenie? Sądzę, że niebagatelne, ponieważ to one inicjują proces lektury tekstu, a następnie go w istotny sposób kształtują. W efekcie nie daje się oddzielić wymiaru graficznego i dyskursywnego ulotki. Śniecikowska uważa, że

[p]ośród kompozycji sprzed stu lat "na oko" najbliżej ulotce do publikowanych w prasie tekstów reklamowych operujących czcionkami różnych wielkości i krojów, zawieszonych między graficznym porządkiem prozy 
i poezji. Podobieństwo do druków reklamowych jest jednak dość powierzchowne, w znacznej mierze - czysto wizualne. ${ }^{21}$

Podobieństwo jest w istocie wizualne, ale to nie znaczy, że powierzchowne. Strategia budowana topografią ma znaczący wpływ na aktywizowanie całościowych sensów ulotki Wata i Sterna. Z pewnością ma działać - w pierwszym kontakcie - właśnie jak doraźny druczek reklamowy niewielkich rozmiarów $(20,8 \times 12,1 \mathrm{~cm})^{22}$, łatwo podatny na zniszczenie (bibułka), sugerujący poniekąd fizycznością własną nieważność i efemeryczność. To jak gdyby antycypacja i realizacja jednocześnie w materialnym wymiarze postulatu dotyczącego chwilowości poezji z późniejszego manifestu Jasieńskiego ${ }^{23}$. To również wyrażone rozchwianym i niezgrabnym drukiem, po pierwsze, polemika z dotychczasowym linearnie uporządkowanym, ustabilizowanym wersyfikacyjnie kształtem tekstu literackiego, zwłaszcza w jego stroficznym bądź stychicznym wydaniu i, po drugie, zerwanie z jednostajnością grafii na rzecz zmienności i dynamiki, co miało zapewne stanowić wizualny ekwiwalent współczesności z jej ciągle przyśpieszającym tempem miejskiego życia, $\mathrm{z}$ aktywizmem i energią, którą dodatkowo wyrażał czerwony kolor - kontrastujący z tłem, ekspresyjny, tak że litery zdawały się wyskakiwać ponad płaszczyznę druku. Nie tyle, a przynajmniej nie tylko, jak chce pierwsza interpretatorka, „kontrasty czerwieni i czerni” kojarzyć można z konstruktywizmem ${ }^{24}$ (w Polsce późniejszym notabene o kilka lat), ale z kolorem rewolucyjnych odezw i ulotek, które były wówczas wszechobecne na ulicach ogarniętej wrzeniem politycznym Europy. Przy tej kwestii warto się zatrzymać i przypomnieć fakty: otóż jesienią 1918 roku (tj. w okresie poprzedzającym ukazanie się ulotki) rewolucja społeczna była tematem niezwykle aktualnym w odradzającej się Polsce, w której brakowało ustabilizowanych struktur władzy i która na wschodzie i na zachodzie sąsiadowała z krajami ogarniętymi rewolucyjnym przewrotem. W listopadzie tego roku silne było przekonanie - w związku z utworzeniem pierwszego rządu II Rzeczypospolitej z socjalistą Jędrzejem

21 Tamże, s. 333.

22 Zob. tamże, s. 331.

Zob. B. Jasieński Manifest w sprawie poezji futurystycznej, w: Antologia polskiego futuryzmu i Nowej Sztuki, wstęp i komentarz oprac. Z. Jarosiński, wybór i przygotowanie tekstów H. Zaworska, Zakład Narodowy im. Ossolińskich, Wrocław 1978, s. 17-22: „Bezwzględna wartość dźeła sztuki waha śę pomiędzy 24 godźinami a miesiącem" (ort. oryg.; s. 22). 
Moraczewskim na czele - że oto w Polsce dokonuje się rewolucja. Atmosfera ta silnie wpływała także na działalność artystyczną - np. ulotka zapraszająca na pierwszy wieczór do kawiarni literackiej Pod Pikadorem miała charakter odezwy; zaczynała się zwrotem: „Rodacy, żołnierze, dzieci, starcy, kobiety, inteligenci i pisarze dramatyczni!", i zawierała sparodiowane proletariackie hasło: „Młodzi artyści Warszawy łączcie się!”.W listopadzie 1918 roku na skamandryckich wieczorach Pod Pikadorem recytowano - co równie znaczące - Carmagnolę, najbardziej radykalną w wymowie część poematu Czarna wiosna Słonimskiego ${ }^{25}$. Aura rewolucyjności wydawała się wówczas wszechogarniająca, nic zatem dziwnego, że oddziałała także na młodocianych admiratorów Nowego i nadała wyraziste piętno ulotce/odezwie TAK.

Powróćmy do druku. Znaczenia wynikające z typografii wspiera porządek leksykalno-składniowy tekstu. Z jednej strony - parodystycznie przywoływany krąg znaczeń młodopolskich, z drugiej - sensy oscylujące wokół nadchodzącego porządku, którego figurą staje się gloryfikowana fizyczność. Istotne wydaje się to, że semantyka tekstu jest tutaj wymiarem budowanym na grafii i poprzez nią, nie istnieje więc samodzielnie, lecz dzięki medium wizualnemu. Jak słusznie zauważyła Agnieszka Karpowicz:

Pozornie pismo alfabetyczne, szczególnie w porządku typograficznym drukowanej stronicy, wydaje się niematerialnym, niemal przezroczystym naczyniem na treść bezpośrednio zapośredniczoną przez mowę. Słowo pisane jest jednak zawsze formą postrzeżeniową, przy czym jej specyfika polega na tym, że patrzymy równocześnie na nią i przez nią. ${ }^{26}$

W wypadku ulotki TAK niewystarczająca jest lektura stricte literaturoznawcza, pomija ona bowiem istotne sensy przekazu i nie pozwala ustabilizować treści skierowanych do odbiorcy komunikatu. Warto zatem zawierzyć najpierw temu, co widzi oko, a dopiero po chwili - temu, co czyta. A w pierwszym momencie widzi rozchwiany, dość chaotyczny druk, w którym uwagę zwraca kilka elementów wyróżniających się spośród pozostałych - bądź to zapisem

25 Por. P. Pietrych "Czarna wiosna” jako „poemat rewolucyjny”, w: tegoż Młodzieńcza twórczość Antoniego Słonimskiego. Teksty i konteksty, Wyższa Szkoła Pedagogiczna im. Jana Kochanowskiego, Kielce 1997, s. 12-42. Antropologia pisma. Od teorii do praktyki, red. Ph. Artières. P. Rodak, Wydawnictwa UW, Warszawa 2010, s. 123. 
wersalikami lub inicjalną wielką literą, bądź to czerwoną barwą. W efekcie najpierw czytamy właśnie te wyróżnione graficznie, jakby wyskakujące z tekstu słowa. Ulotka domaga się więc percepcji nie linearnej, lecz takiej, której rytm wyznaczają wyróżnione na różne sposoby słowa, pełniące w trakcie lektury funkcję swoistych punktów orientacyjnych o charakterze wizualnym. Jak pisze Bert Schnettler:

[w] przeciwieństwie do tekstu, przy użyciu obrazów możliwa jest symultaniczna reprezentacja najbardziej kompleksowych zjawisk, pojawiających się w jednym momencie, która nie rozwija się sukcesywnie czy po kolei, jak w linearnej argumentacji tekstowej. Środki ikoniczne podlegają innym prawom strukturacji i wyrażania i ustanawiają inne zależności pomiędzy ich składnikami niż teksty. Obrazów nie da się ostatecznie zwerbalizować w ten sam sposób co pismo, a możliwości translacji wizualnych reprezentacji wydają się w porównaniu z tekstami jeśli nie ograniczone, to co najmniej podlegające innym regułom. ${ }^{27}$

Inicjalne TAK „krzyczy” właśnie - po pierwsze - sposobem zapisu i umiejscowieniem pośród innych elementów na "obrazie”, a dopiero, po drugie, przez występowanie w bliskim kontekście słów: „wrzaskiem i „rżorykiem”. Nie mogę się zatem zgodzić z interpretacją pierwszej badaczki ulotki, piszącej:

Tak. Jaki łagodny początek. Zaskakujący w kontekście tytułów późniejszych futurystycznych manifestów i jednodniówek [...]. Tak. Afirmacja. Spokój. Zgoda.

Czy to jednak aby najlepszy szyld dla pierwszego wystąpienia artystycznych wichrzycieli? Takie zawołanie na rewolucyjny początek?! Gdyby upierać się przy chwytliwych, krótkich partykułach - o wiele lepsze wydaje się "nie". ${ }^{28}$

Jeśli czytać „TAK” zapisane wielkimi literami, niepodobna wyczytać tu łagodności, spokoju, a nawet zgody.To „TAK” krzyczy, coś afirmując, ale jeszcze

B. Schnettler W stronę socjologii wiedzy wizualnej, „Przegląd Socjologii Jakościowej” 2008 t. 4, nr 3, s. 122, http://www.qualitativesociologyreview. org/PL/Volume8/PSJ_4_3_Schnettler.pdf; cyt. za: J. Budzińska Planimetria obrazu , „Sensu Historiae" 2012 t. 6, nr 1, s. 116, http://www.sensushistoriae.epigram.eu/index.php/czasopismo/article/view/58/55 (10.02.2012). 
nie wiemy co. Choć Śniecikowska przywołuje wariant zasugerowany przez Pawła Grafa: „może to istotnie «Tak - rzucone nadejściu nowych antymetafizycznych czasów i wykrzyczane w tytule manifestu»"? ${ }^{29}$, czyni to jednak trybem hipotezy, której nie poddaje ostatecznej weryfikacji, niejako z góry przyjmując, że jest błędna. Odwołuje się nawet do fragmentu późniejszej korespondencji Wata i Sterna, wytłuszczając znaczące zdanie z listu autora Futuryzji: „Gdzież są te czasy, gdy wszystko rozstrzygało się bezapelacyjnie krótkim «Tak»?"30, ale nie dowierza pamięci twórcy jednodniówki. A przecież owo aprobatywne „bezapelacyjnie krótkie «Tak»” zyskuje w ulotce jednoznaczny sens: to TAK wykrzyczane przez NEOFUTURÓW afirmujących SIEBIE w glorzystym Pramuskule. Jeśli więc uwzględnimy kształt druku odnajdziemy po chwili poszukiwany sens - wyznaczają go bowiem te fragmenty, które przez zabiegi typograficzne widzimy/czytamy jako pierwsze ze względu na ich wizualną odrębność. Podkreślmy: dzieje się to przez lekturę nie linearną, lecz nawigującą pomiędzy wyróżnionymi fragmentami tekstu. Właśnie graficzna odmienność sugeruje ich nadrzędność w stosunku do pozostałego tekstu, a więc wydobywa wyjątkowe, tzn. uprzywilejowane znaczenie tego, co w ten sposób jest przekazywane ${ }^{31}$. A przekaz można mniej więcej tak zrekonstruować, biorąc pod uwagę wymiar ikoniczny: neofuturzy mówią „Tak” sobie samym, swej sile i fizyczności oraz oczekują nadejścia „Niego”, prosząc: „PRZYJDŹ". Dopiero teraz otwiera się droga do szczegółowej lektury tekstu

29 Tamże, s. 337; P. Graf Automobil w pędzie, s. 21.

30 B. Śniecikowska TAKodnalezione!, s. 337.

31 Warto zwrócić uwagę na podobieństwo takiego postępowania z metodą interpretacji obrazów Maxa Imdahla: „ikoniczna struktura poddaje się [...] odpowiadającemu jej ikonicznemu sposobowi podejścia do obrazu, który można również nazwać «ikoniką» i który, w odróżnieniu od ikonografii i ikonologii oprócz elementów dzieła figuralnych, rzeczowych czyli rozpoznawalnych w sposób naturalno-przedmiotowy, postrzega również drugą stronę znaczenia wszelkich nośników przedmiotowych - relacje formalne, takie jak zwykłe linie czy elementy kierunkowe. Podejście ikoniczne, czyli ikonika, czyni obraz dostępnym jako fenomen, w którym widzenie przedmiotowe, rozpoznające, i widzenie formalne, widzące, wspomagają się nawzajem w osiągnięciu oglądu wyższego porządku i wyższego układu znaczeń, które zdecydowanie wykraczają poza praktyczne doświadczenia wzrokowe. [...] [W]łaściwej treści obrazu upatruje nie w «symbolicznej wartości» jakiegoś modusu uznanego za reprezentatywny dla tendencji ogólnej, którą można sformułować także w innych mediach, lecz bardziej [...] w obrazie jako propozycji wizualnej, która wyrażając oczywistość oglądową i tylko oglądowi dostępną, wykracza poza wszystkie nagromadzone oczekiwania wizualne, jak również poza wszystkie przekazane językowo wyobrażenia danego wydarzenia" (M. Imdahl Giotto. Z zagadnień ikonicznej struktury sensu, przeł. T. Żuchowski, "Artium Quaestiones” 1990 t. 4, red. K. Kalinowski, s. 107; cyt. za: J. Budzińska Planimetria obrazu, s. 121-122). 
werbalnego. To zadanie wykonała w dużej mierze Beata Śniecikowska, prowadząc nas przez „meandry mikrolektury”32. Szlak jej działań wytycza, po pierwsze, pominięcie różnic w zapisie poszczególnych fragmentów tekstu widniejącego na ulotce, po drugie, uznanie, że druk ,jawi się jako... bezrymowy syntagmatyczny wiersz wolny" ${ }^{\prime 3}$, po trzecie, przyjęta metodologia: analiza literaturoznawcza. Badaczka tak konkluduje swoje dociekania:

Drobiazgowa mikrolektura Tak pozwoliła na przywołanie najróżniejszych kontekstów badawczych, nie udało się jednak wytyczyć konkretnej, wyrazistej ścieżki interpretacji. Nie widzę także w przenicowanej analitycznie ulotce dających się spójnie rekonstruować śladów programu artystycznego świeżo powstałej dwuosobowej grupy twórczej. Brakuje tu również wyraźnych świadectw „nakierowania na kontakt z odbiorcą” - mimo wyboru tak egalitarnej [...] formy publikacji ${ }^{34}$.

Zacznijmy od końca. Jeśli za „wyraźne świadectwo” kontaktu z odbiorcą uznać jedynie bezpośrednio do niego kierowane pytania czy zwroty - to w istocie ich nie ma. Jednak kontakt nawiązywany jest właśnie w sposób egalitarny za pomocą innych strategii. Najważniejsze wydają się tu zabiegi typograficzne. Kształt wizualny TAK wyznacza bowiem specyficzny tryb lektury - odbiorca (może nim być np. przechodzień) „czyta” (lepiej chyba powiedzieć: widzi i czyta jednocześnie) nie linearnie, ale punktowo, łącząc z sobą najpierw „ważniejsze” graficznie fragmenty. Przedmiotem jego percepcji jest szczególny, budowany słowami obraz, którego plan pierwszy wyznaczają wyrazy zapisane wersalikami (bądź wielką literą) i kolorem czerwonym, dopiero potem pojawiają się w polu widzenia "leksykalne obiekty" drukowane czcionką mniejszą (czasem również czerwoną). To proces zgodny z temporalnym trybem postrzegania - najpierw widzimy elementy duże, później mniejsze. Nie mamy tu więc do czynienia z jednostajnym oglądem całości, lecz z procesem rozłożonym na fazy (krótkie niczym mgnienie oka), którego etapy nie następują „po kolei”, ale migotliwie, wywoływane jakościami wizualnymi. Widzenie w taki sposób jest jak oglądanie obrazu - najpierw postrzegamy elementy większe i barwniejsze, by w miarę coraz uważniejszego patrzenia 
odkrywać składniki drobniejsze, zrazu mniej „rzucające się w oczy”.Z pewnej odległości widzimy tylko „plan pierwszy”, a gubimy detale - aby je „odzyskać”, musimy spojrzeć inaczej, przekształcić własną percepcję. Tak właśnie przebiega „lektura” ulotki TAK. Odbiorca jest atakowany wizualnym kształtem obiektu, co jest skutkiem świadomych zabiegów autorskich, zmierzających do intensyfikacji odziaływania, a w efekcie prowadzi do emocjonalnej reakcji (choćby negatywnej, wpisanej w strategię skandalu) ze strony drugiego uczestnika procesu komunikacji.

Co do kwestii drugiej - „wytyczenia wyrazistej ścieżki interpretacji” sądzę, że wskazują jej kierunek słowa samego autora, które warto jeszcze raz przytoczyć: „[ulotka - K.P.] głosiła bezwzględną aprobatę dzisiejszości". W Moim wieku Wat mówi więcej o atmosferze towarzyszącej pierwszym wystąpieniom:

[...] był jakiśfeeling, emocjonalne ciągoty, więc przede wszystkim potrzeba intelektualna, ale również emocjonalna całkowitej odnowy, to znaczy [...] poczucie, że nastąpiło jakieś trzęsienie ziemi [...].

[...] było walenie się, ruiny à la longue wesołe ruiny, [...] przedmiot do wesela duchowego, bo tu można właśnie coś nowego zbudować, to jest wielka niewiadoma, podróż w niewiadome, wielkie nadzieje, z tego, z tych ruin właśnie... ${ }^{35}$

Zgodnie z intencją autorską, która stanowi w tym wypadku niezbywalny kontekst, TAK należałoby czytać jako anarchizujący tekst wymierzony we wczorajsze ideały, apoteozujący współczesność, zapowiadający nadejście nowego jutra i gloryfikujący fizyczność, siłę i dynamikę jako figury wyczekiwanej przyszłości36.

Ale nie tylko przywoływana za paratekstami intencja autorska stanowi argument w kwestii wyznaczenia zasadniczego kierunku interpretacji. Wszak

A. Wat Mój wiek. Pamiętnik mówiony, t. 1, rozmowy poprowadził i przedmową opatrzył C. Miłosz, do druku przygotowała L. Ciołkoszowa, Czytelnik, Warszawa 1998, s. 26-27.

Warto przy okazji odnotować istotną w tym kontekście uwagę Sterna, odnoszącą się do jednodniówki Gga, kolejnej wspólnej publikacji programowej: „Pierwsze słowa manifestu nawiązywały do naszej pierwszej chronologicznie wypowiedzi w wydanej przez nas jeszcze w r. 1919 małej kolorowej ulotce pt. Tak. Brzmiały one: «Wielka tęczowa małpa zwana dionizosem dawno już zdechła»" (A. Stern Futuryści polscy i inni, w: tegoż Poezja zbuntowana. Szkice i wspomnienia, PIW, Warszawa 1970, s. 50). To zatem, co stare i co musi odejść, Stern utożsamia jednoznacznie, w duchu młodopolskim, z Dionizosem. 
zarówno sądy Sterna, jak i Wata formułowane były z dużego dystansu czasowego, można więc żywić co do ich prawdziwości uzasadnioną wątpliwość. Mamy jednak także dowód immanentny - jeśli wziąć pod uwagę gradację ważności poszczególnych części druku widniejącego na ulotce, wynikającą z zastosowanej typografii, to wówczas analiza winna być przeprowadzona z uwzględnieniem intermedialnej poetyki ulotki. A zatem nadrzędność znaczeń wydobyta zabiegami graficznymi nakazuje najpierw dostrzec, przypominam, owo TAK wykrzyczane przez NEOFUTURÓW afirmujących SIEBIE w glorzystym Pramuskule, by potem dopiero wskazać znaczenia „pomniejsze". Gradacja ma tu zasadnicze znaczenie - kieruje naszą uwagę na to, co najważniejsze, natomiast "mniejsze" - nie tylko rozmiarem, ale i semantyką - elementy, moim zdaniem, nie domagają się wcale tak drobiazgowej deszyfrującej analizy, która prowadzić nas może właśnie w niebezpieczne „meandry mikrolektury". Ulotka/odezwa nie jest bowiem skonstruowana wedle reguł wiersza symbolistycznego o niejasnym znaczeniu, lecz wykorzystuje różne clichés młodopolskiej estetyki niczym gotowe klocki, układając je w parodystyczną całość. Podobny zabieg zastosuje Wat nieco później, konstruując poemat JA z jednej strony iJA z drugiej strony mego mopsożelaznego piecyka (1920), utwór, rzec można, ekstremalnie intertekstualny, w którym obrazoburcza krytyka wszelkich (choć przede wszystkim modernistycznych) kodów kulturowych sięga zenitu. Słusznie rzecz zdiagnozował Tomas Venclowa:

Wyrwane z naturalnego sąsiedztwa, torturowane, przeinaczane, niszczone słowo w Mopsożelaznym piecyku traci swój walor symboliczny. Zachowuje jakość metajęzykową: jest słowem i niczym innym. Każde słowo może zostać postawione w sąsiedztwie z każdym innym i utworzyć jednak z nim związek - pojawią się wówczas dowolne obrazy, które wynikną z tej operacji. [...] Tak oto okazuje się, że immanentny autorytet znaku i języka pozbawiony jest pokrycia $[\ldots] .{ }^{37}$

Ta strategia, niedoprowadzona jeszcze do apogeum, rządzi też w ulotce TAK: użyte przez młodych awangardzistów słowa nie zostały co prawda uwolnione z reguł językowych (morfologicznych, składniowych i semantycznych), ale pozbawione zostały swego "naturalnego sąsiedztwa”, tzn. pierwotnego kontekstu kulturowego, nadto zyskały wolność w wymiarze przestrzennym,

37 T. Venclova Aleksander Wat. Obrazoburca, przeł. J. Goślicki, Wydawnictwo Literackie, Kraków 1997, s. 92. 
wyswobadzając się z nazbyt sztywnego linearnego porządku pisma. Te zabiegi, w których stawką najważniejszą jest zanegowanie funkcji referencyjnej znaku, jego związków z rzeczywistością pozaliteracką, prowadzą do tego, że słowa ostentacyjnie ujawniają przede wszystkim swój tekstualny potencjał. Podążanie zatem w lekturze ulotki za sensami symbolicznymi i metaforycznymi wydaje się działaniem sprzecznym z taktyką, jaką obrali autorzy.

I kwestia trzecia. Neofuturzy kreślą najpierw, nonszalancko i blasfemicznie, program negatywny, odrzucający wszelkie metafizyczno-estetyczne wartości młodopolskie. Dalecy są przy tym od formułowania swych idei w sposób racjonalny i dyskursywny - zresztą krzyk, którym się posługują, ze swej istoty takich wyważonych cech jest pozbawiony. Ale przecież poza negacją także coś wybierają, choć nie wyrażają tego w jasno formułowanych postulatach.To, co proponują, istotnie nie spełnia kryteriów manifestu zgodnych ze słownikową definicją ${ }^{38}$. Z dzisiejszej perspektywy widać jednak wyraźnie, że młodzi neofuturzy dokonali pozytywnego samookreślenia nie na poziomie explicite wyrażonych haseł i idei (tak jak uczynią później na dwa odmienne sposoby Jasieński i Peiper), lecz na poziomie "meta” - poprzez działania intermedialne, prowadzące do powstania nowego wewnętrznie heterogenicznego obiektu. W TAK łączą się ze sobą jakości wizualne i werbalne, dając początek nowemu (inter)medium, oddziałującemu swoistą "przechodniością" zastosowanych tworzyw i jednocześnie stanowiącemu ich syntezę. Tylko bowiem w swym złożonym kształcie graficzno-językowym ulotka neofuturów aktywizuje pełną funkcjonalność semantyczną - czynnik wizualny nie może tu zatem zostać sprowadzony do roli ornamentacyjnego dodatku. Przeciwnie, ikoniczny wymiar pierwszego polskiego manifestu, destabilizując werbalne

38 Warto zauważyć, że przyjęta za Słownikiem terminów literackich definicja manifestu pochodzi z apogeum myślenia strukturalistycznego i nie uwzględnia historyczności, złożoności i zmienności gatunków. Jeśli poszlibyśmy np. za propozycją Derridy twierdzącego, że "normatywna siła prawa gatunku zakłada własne zakłócenia", dostrzeglibyśmy, iż mamy współcześnie do czynienia „z badaniami nad hybrydycznością, przygodnością i wyjątkiem jako zjawiskami centralnymi dla całej teorii" (I. Nelson, S. Gayk Gatunekjako forma życia, przeł. G. Grochowski, „Teksty Drugie" 2019 nr 3, s. 169). Wtłoczenie ulotki TAK w sztywne ramy "naukowej" taksonomii genologicznej wydaje się z góry skazane na niepowodzenie. Ciekawsza i bardziej adekwatna w tej sytuacji wydaje się choćby poststrukturalistyczna propozycja zastąpienia „prawa” gatunku "regułą" gatunkową, co postulują Ingrid Nelson i Shanon Gayk, podążające tropem Agambena. Trop to tym istotniejszy, że łączy współczesną refleksję genologiczną nie z normatywną teorią gatunków, lecz z "formą życia", z doświadczeniem, a zatem z tym, co było szczególnie ważne dla Sterna i Wata w ich młodzieńczych wystąpieniach, silnie wiążących działania twórcze z egzystencją. 
sensy, nadaje im jednocześnie dynamiczną procesualność, sprawia, że mamy do czynienia z wypowiedzią o charakterze performatywnym - chcącą oddziaływać skutecznie na rzeczywistość pozawerbalną oraz kształtować nowe jutro. Niewielka, ongiś błękitna, ulotka - wspólne „rewolucyjne dzieło” nastoletnich Sterna i Wata - eksponująca własną "graficzną materialność"39, była niczym jeden z elementów ówczesnej, ale w jakiejś mierze i dzisiejszej przestrzeni wizualnej, budowanej przez „szyldy, napisy reklamowe, plakaty, wystawy sklepowe oraz witryny kiosków prezentujące typograficzne słowa na okładkach magazynów, pudełkach papierosów lub opakowaniach gumy do żucia"40. Wkraczała w ten sposób

w wizualną przestrzeń - zauważa Karpowicz - codziennego życia, a także [...] w publiczną i prywatną przestrzeń audialną. Ten wielkomiejski hałas futuryści chcieli wprowadzić także w milczącą przestrzeń obrazu lub drukowanej stronicy [...]. Zgiełk na kartce papieru miał według futurystów uobecniać w doświadczeniu bezpośrednim hałaśliwą rzeczywistość współczesnego im miasta. ${ }^{41}$

Młodociani warszawscy neofuturzy taki właśnie program realizowali i choć w swym wystąpieniu nie byli aż tak radykalni jak ich zachodni koledzy, to jednak odrzucając wszystko, co wyłoniło się z „błotka Mglistego”, opiewali „szaleństwo rozżarzonych kraterów miast” - w sposób dziś z pewnością mało oryginalny, ale naonczas rewolucyjny - ekwiwalentyzując wizualnie „wybuchowe jakości” kwestionującym statyczność pisma drukiem na ulotce.

Rozpatrując pierwsze awangardowe dokonanie Sterna i Wata w perspektywie komparatystycznej, dostrzega się, że jest to medium mieszane, łączące różne kody i adresowane do różnych praktyk percepcyjnych, nakierowanych zarówno na aspekt ikoniczny, jak i na komunikat werbalny. Wykorzystuje ono niezwykły układ drukarski, posługuje się liternictwem różnej wielkości i różnego koloru, sytuując je na barwnym tle, co w konsekwencji burzy jednostajność płaszczyzny przekazu, proponując w to miejsce ekspresywność i dynamikę, wymagające od odbiorcy większej kreatywności i innowacyjności

A. Karpowicz, Wizualność-pisemność, s. 124.

40 Tamże, s. 125.

41 Tamże, s. 128. 
w odczytywaniu znaczeń. Arsenał użytych środków w efekcie znacznie zwiększa siłę oddziaływania i tworzy przekaz celowy i funkcjonalny, adekwatny do jego semantyki. Zastosowana typografia nie jest jedynie wizualnym dodatkiem do treści komunikatu, lecz aktywnie go modyfikuje i współtworzy.

Ulotka TAK uświadamia ważny aspekt młodzieńczych poszukiwań i eksperymentów „neofuturów”, którzy w mniejszym stopniu wykorzystują potencjał znaczeniowy języka, w większym - „złożony”, wizualno-słowny, charakter przekazu. Wat w rozmowie z Miłoszem powiedział, że chodziło mu wówczas o "gniecenie słowa”, „niszczenie słowa"42 - nie tylko w jego wymiarze akustycznym czy semantycznym, lecz także, jak się okazuje, ikonicznym. Taki stosunek do języka jako materii, możliwość używania go niczym gliny sprawia, że elementy pierwotnie werbalne stają się formami wizualnymi. Usytuowanie tego młodzieńczego intermedium w horyzoncie zwrotu pikturalnego pozwala odkryć i docenić „wyparty z kultury obrazowy sposób ustanawiania znaczenia/widzialności”“3 oraz uświadomić, że bez obrazu - swego materialnego, nieprzezroczystego nośnika - zapisane słowo nie istnieje.

\section{Abstract}

\section{Krystyna Pietrych}

UNIVERSITYOF ŁÓDŹ

The Pamphlet TAK: Reading from an Intermedia Perspective

Pietrych polemicises with the literature-centric reading of the Polish Futurists' first publication and proposes instead a reading rooted in intermedia comparativism and the image turn. Such a method makes it possible to treat the pamphlet TAK as a structurally heterogeneous statement that first harnesses the semantics of typography before engaging the meanings of words. This allows Pietrych to indicate unambiguous meanings of the avant-gardists' disruptive and innovative manifesto.

\section{Keywords}

comparative studies, intermediality, image turn, manifesto, avant-garde

42 A. Wat Mój wiek, t. 1, s. 45.

43 A. Kałuża Poezja i obraz, piśmienność i wizualność, s. 52. 